\title{
INTERNATIONAL INSTRUMENTS RELATING TO CONSERVATION OF PLANT BIODIVERSITY
}

\author{
Gabriela ROMANCIUC \\ Institute of Genetics, Physiology and Plant Protection, Chisinau, \\ Republic of Moldova
}

\begin{abstract}
This paper reviews the international instruments related to the conservation and sustainable use of plant biodiversity, including agreements, governance and programs, such as the Convention on Biological Diversity, the FAO Global Plan of Action on Plant Genetic Resources, the International Treaty on Plant Genetic Resources for Food and Agriculture.

Key words: biodiversity, conservation, international instruments, Convention of Biological Diversity (CBD), Global Plan Actions (GPA), the International Treaty on Plant Genetic Resources for Food and Agriculture (IT-PGRFA)
\end{abstract}

Many plant species are threatened by habitat transformation, over-exploitation, invasive alien species, pollution and climate change, and are now in danger of extinction. In this condition, we should focus our efforts on saving species or the habitats in which they occur. Exploration, collection, characterization, evaluation and documentation are the main principles of plant boidiversity conservation. Ex-situ (storing diversity in gene banks) and in-situ (on-farm) conservation are the strategies mainly used for their preservation.

The international instruments impacting plant genetic resources management include the international treaties, conventions, agreements. According to the objectives, the present international instruments can be divided in two main categories [Derek,2004; Sonnino, 2017]:

- those focused on the conservation and sustainable use of plant genetic resources, such as the Convention on Biological Diversity (CBD), the FAO Global Plan of Action on Plant Genetic Resources (GPA), the International Treaty on Plant Genetic Resources for Food and Agriculture (IT-PGRFA);

- those aiming to protect intellectual property, such as the agreement on Trade Related Aspects of Intellectual Property Rights (TRIPS), (inter)national patent legislation, and sui generis systems of intellectual property protection such as the plant breeder's right under the International Convention for the Protection of New Varieties of Plants (the UPOV Convention).

Convention of Biological Diversity (1992) is the international legal instrument for "the conservation of biological diversity, the sustainable use of its components and the fair and equitable sharing of the benefits arising out of the utilization of genetic resources" that has been ratified by 196 nations. The Convention is reinforced with two important protocols: the Cartagena Protocol on Biosafety; the Nagoya Protocol on Access to Genetic Resources and the Fair and Equitable Sharing of Benefits Arising from their Utilization (ABS). In 2010, at the Tenth Meeting of the Conference of the Parties to the CBD (Nagoya, Japan), the Strategic Plan for Biodiversity 2011-2020, with its 20 Aichi Biodiversity Targets and a strategy for mobilizing resources were adopted.

States play a fundamental role in the success of implementing the Convention. 
They are entrusted with fundamental roles that range from implementing preservation strategies to organizing data regarding biological resources. States also have an obligation to identify components of biological diversity, and to maintain and organize this information. The Republic of Moldova is part of the UN Convention on Biological Diversity from 1995 and ratified its two Protocols - the Cartagena Protocol on Biosafety (2003), including the Nagoya - Kuala Lumpur Supplementary Protocol on Liability and Redress to the Cartagena Protocol on Biosafety Protocol Biosafety and the Nagoya Protocol on Access and Benefit Sharing (2016). Also, National Biodiversity Strategy and Action Plan for 2015-2020 was approved by Government Resolution No. 274 of 18.05.2015.

Global Plan Actions (GPAs 1 - 1996 and GPAs II - 2011), is an efficient system for the conservation and sustainable use of genetic resources for food and agriculture. GPAs are intended as comprehensive frameworks to guide and catalyze action at community, national, regional and international levels. They contain sets of recommendations and priority activities that respond to the needs and priorities identified in global assessments: the reports on the state of the world's genetic resources for food and agriculture.

International Treaty on Plant Genetic Resources for Food and Agriculture (2001) multilateral international agreement for the fair and equitable sharing of benefits arising from the use of to plant genetic resources for food and agriculture (PGRFA). To date, 144 countries have signed the International Treaty. The key elements of the ITPGRFA are: the conservation, exploration, collection, characterization, evaluation and documentation of PGRFA; the Sustainable Use of Plant Genetic Resources; Farmers' Rights; a Multilateral System of Access and Benefit-sharing (MLS); and a Funding Strategy. In 2015 the Republic of Moldova ratified the ITPGRFA, by the Law no. 94 of 14.05.2015

International instruments work to implement actions at the national, regional and international level in order to reach shared goals of conservation and sustainable use plant biodiversity.

\section{BIBLIOGRAPHY}

1. Eaton Derek, Kalaugher Electra, Bijman Jos. International agreements relating to plant genetic resources for food and agriculture and implications for Dutch policy. The Hague, Agricultural Economics Research Institute (LEI), 2004 Report 6.04.06; ISBN 90-5242-896-4

2. Sonnino Andrea. International Instruments for Conservation and Sustainable Use of Plant Genetic Resources for Food and Agriculture: An Historical Appraisal. In: Diversity 2017, 9, 50; doi: $10.3390 / \mathrm{d} 9040050$ 